\title{
Open Innovation, a Tool for Globalization: The Case of South Korean SMEs
}

\author{
Rara Hye-Seong Jeon \\ Trident University \\ Korea Venture Business Association \\ Daniel Degravel \\ California State University, Northridge
}

This study explores the phenomenon of open innovation in high tech Korean SMEs. Which mechanisms do lead SMEs to choose a specific model of innovation?

The paper includes a literature review as well as an empirical study of internationalized SMEs, based on in-depth interviews, observations, and documents.

Open innovation does not always constitute the best model of innovation solution for all SME. This paper proposes a model for assessing the fit between a company and the various models of innovation, and a strategic guide to design an innovation model for successful collaboration with the best partners.

\section{INTRODUCTION}

\section{A Complex but Interesting Phenomenon}

Development through globalization, understood as the presence of transactions across borders, is increasingly taking place in the business world, involving firms of all sizes. A critical ingredient for globalization resides in innovation, defined as "the multi-stage process whereby organizations transform ideas into new/improved products, services, or processes, in order to advance, compete, and differentiate themselves successfully in their marketplace" (Baregheh, Rowley, \& Sambrook, 2009:1334).

Among the various modalities of innovation models, "Open innovation" (called thereafter "OI") is defined as "both a set of practices for profiting from innovation, and also a cognitive model for creating, interpreting and researching those practices" (Chesbrough et al., 2006:1). Intensive competition in some domestic markets may motivate a technology expansion into new markets abroad (Henttonen, 2013; Kang, 2012). Increased uncertainty in the marketplace has caused a fundamental change in firms' innovation strategy, using OI to increase the effectiveness of their innovative effort.

\section{A Valuable Field for Research}

The literature indicates that differences for OI exist related to the size of the firms: most large and multinational firms commonly implement OI (Wynarczyk, Piperopoulos, \& McAdam, 2013) whereas SMEs resist to do so because they lack experience and knowledge about OI best practices (Kang, 2012). 
Whereas large firms are focused on the early stage of OI, i.e. the R\&D phase, smaller firms implement OI at all stages of the innovation phenomenon, and especially during the collaboration, commercialization and/or marketing phases.

Most SMEs conduct R\&D by themselves (in-house) rather than via collaboration with partners. This situation arises from various challenges associated with OI (for example protecting ownership of technology or mitigating risks from partnerships). These challenges and the potential benefits of using OI for globalization and success constitute a reason for undertaking this exploratory study. Another reason lies in the relative weakness of studies related to our specific South Korean context of research and the exclusion of SMEs from the main stream discussion of OI (Lee et al., 2010). Several authors have called for international collaboration to study innovation because of the critical questions that global collaboration raises (Ebersberger \& Herstad, 2013), and because OI has become commonplace in organizations (Alexy, Bascavusoglu-Moreau, \& Salter, 2016).

Moreover, OI is a complex phenomenon and requires a more inclusive treatment and integration of various streams of academic discourse such as globalization of R\&D and innovation, supplier integration, and application of technology (Lazzarotti \& Manzini, 2009; Patra \& Krishna, 2015).

\section{The Study and its Attributes}

Our study explores the OI phenomenon in a South Korean context, when implemented by SMEs operating in a high technology environment. We aim at understanding the relationship between OI and globalization in this context to suggest recommendations to improve the effectiveness of this strategy when used by SMEs. To achieve this goal, we analyze how different modalities of collaboration impact these SMEs' globalization.

The empirical research in the studies examines several case studies to analyze how high-tech industries SMEs implement OI in global markets. The material collected through interviews and through secondary research is processed using a qualitative method to extract meanings and capture patterns of behavior for practicing firms.

The first section of this article reviews the literature relevant to the central topic of OI, but also to peripheral concepts that form the context of this core topic such as globalization, innovation, SMEs, $\mathrm{R} \& \mathrm{D}$, and collaboration.

The second section presents the research itself and describes its methodology and attributes, including the processing of information and the used tools.

A third section describes the findings of the study, including the consequences and antecedents of OI for the SMEs, and the contributions and implications at the managerial and theoretical levels.

\section{REVIEW OF LITERATURE}

\section{Globalization}

Globalization is a broad concept used to describe a variety of phenomenon that reflect the developed economic, social, and political interdependence of countries (Nik Ab Halim \& Zain, 2011). Despite growing awareness, there is no generally accepted definition and no standard measurement of globalization (Asmussen, Pedersen, \& Petersen, 2007). We define in this paper globalization as the efficient movement of goods, services, capital, people, and ideas across national borders (Little \& Green, 2009).

Globalization translates into a large range of business modalities for organizations that share a common trait: something or someone is crossing borders. A classic typology is such modalities includes exportation and importation; foreign direct investment; international partnerships; international licensing and franchising; and contract-based operations (Hill \& Jones, 2012; Archibugi \& Iammarino, 2002).

Organizational size appears to differentiate the benefit of globalization for companies: globalization tends to benefit large firms compared to SMEs because scale advantages allow large firms to create new opportunities and to benefit from a larger amount of resources to optimize their operations. As a 
consequence of the entry of larger companies in their domestic markets, SMEs are faced with increasing prices and technological competition from large firms (Peters \& Schmiele, 2010).

Because globalization is a dynamic and interactive process, innovation is a key ingredient in the globalization phenomenon. Most firms need to innovate to stay competitive and to meet global standards. Let us know turn to the central topic of innovation.

\section{Innovation}

Innovation can be defined as the "process of idea generation, technology development, and manufacturing and marketing of products and/or services" (Desouza, Dombrowski, Awazu, \& Baloh, 2007). Felin and Zenger define innovation as "the process by which existing knowledge and inputs are creatively and efficiently recombined to create new and valuable outputs" (Felin \& Zenger, 2014:915). For Zeng, Xie, and Tam (2010), innovation is the process which results from various interactions among different actors and cross- sectoral networks that accelerate flows of information, resources, ideas, trust, and individuals.

Innovation is essential for an organization's growth (Horibe, 2003) to improve its competitive position (Baregheh, Rowley, \& Sambrook, 2009). It is widely considered to play a central role in creating value, sustaining competitive advantage, and representing the evolution in any organization (Baregheh, Rowley, \& Sambrook, 2009).

Because innovation was originally linked to the role of $R \& D$ and is the most significant strategy in technological companies (Conte \& Vivarelli, 2014), we will focus on the R\&D component of technological innovation, emphasizing the high-tech industry as the target of our empirical research. Technological innovation constitutes the heart of innovation and is critical to globalization (Abdullah \& Zain, 2011; Verweij et al., 2012). Various scholars have pointed that successful technological innovation requires technological capabilities and management skills (Kang, 2012; Johnson, Arya, \& Mirchandani, 2013). Technological innovation is considered as an imperative.

Technological innovation is the process of developing the new idea into a product and/or service and constitutes a combination of technical, industrial, and commercial operations (Tohidi \& Jabbari, 2012; Wynarczyk, Piperopoulos, \& McAdam, 2013). Understanding the process of innovation allows firms to achieve greater efficiency in production and quality (Lawson \& Samson, 2001; Thorgren et al., 2012; Un \& Asakawa, 2015). Moreover, high-tech and rapidly-changing industries require significant R\&D investment associated with high risk (Belderbos et al., 2006). R\&D contributes to a rise in export capacity and lowers the business risk associated with firms' activities.

Conte and Vivarelli (according to their Extension Market model) explain that innovation is the result of consumer demands and market needs. Consumers, potential buyers, distributors, and strategic partners express demands, which directly affect technology development (Conte \& Vivarelli, 2014).

\section{Open Innovation}

The paper central theme, OI, was first proposed by Chesbrough (2005) to describe how knowledge and technology are increasingly benefiting from the integration of ideas and capabilities from multiple sources. The key idea behind OI is to engage with different types of partners "to acquire ideas and resources from the external environment to stay abreast of competition" (Dahlander \& Gann, 2010:699). In 2006, Chesbrough and colleagues defined OI as a set of practices for profiting from innovation but also a cognitive model for creating, interpreting, and researching those practices (Solesvik \& Gulbrandsen, 2013). All definitions are based on the idea that valuable novelties related to the path to market can come from inside as well as outside the organization (Lee at al., 2010).Various objects of OI exist including business model, product, technological, and transfer management (Hossain, 2015).

According to Suh and Kim (2012), OI include four components: technology acquisition transfer; R\&D collaboration; joint venture; and networking. Wikhamn and Sthyre (2016) propose a four-phase process of OI including: obtaining, evaluating, selecting, and applying an innovation. Enkel et al. (2009) highlight three components of the OI process: 1) outside-in (integrating external knowledge, customers, and suppliers); inside-out (bringing ideas to market; selling and licensing intellectual property, and 
multiplying technology); and 3) coupled Process (Couple outside-in and inside-out process, working in alliances with complementary organizations).

OI has existed for a long time (Dahlander \& Gann, 2010). However, a set of powerful changes has put it at the forefront of research and of managers' interests. Because of rapidly changing global market conditions and an increasing need for competitiveness, firms are pushed to find partners through networks to boost their innovation (Lee, Park, Yoon, \& Park, 2010). Globalization has expanded the scope of potential markets and competition; an improved infrastructure in the world allows for organizations to trade ideas more easily. New technologies facilitate communication across large distances (Dahlander \& Gann, 2010). Thus, the OI phenomenon has found more resonance in the academic literature (Patra \& Krishna, 2015) as many drivers of interest have come to the forefront: shorter technology life cycles, emerging technologies, rising costs, and risks associated with technological innovation (Enkel et al., 2009; Lee, Park, Yoon, \& Park, 2010; Vanhaverbeke, 2011; Thorgren et al., 2012; Henttonen, 2013), vertical disintegration, modularization and outsourcing, the growth of specialized markets, and the difficulties for SME in capturing the product of their investment in intangibles (Mina, Bascavusoglu-Moreau, \& Hughes, 2014). For Felin and Zenger (2014), several reasons explain the interest and development of OI: a) the development of technologies and the reduction of communication costs enable the connection of many players with disparate knowledge; b) firms have been able to decrease problems complexity by decomposing complex problems into smaller sub-problems; c) the effectiveness of the connecting platforms and the network externalities phenomenon have increase the likelihood of solving problems thanks to a wide broadcast of this problem, and finally d) the connecting platforms thrive on using the individual players motivations and preferences to sustain the model of exchange.

Beneficial networks for firms include: similar firms, customers, suppliers (Kamalian, Rashki, Hemmat, \& Jolfaie, 2015), distributors, and experts who understand market phenomenon. These various partners play a distinctive role in the innovation process.

Ivanov (2014) notes that innovation is valuable but appears as a strange product of the economy based on creativity, because of its unpredictability and associated risk. A response to this situation lies in the opening of the economic actors towards external influence, another way to describe OI.

\section{Consequences of Open Innovation}

It seems reasonable to believe that collaborating with foreign partners could be more beneficial for firms to globalize than collaborating with local partners or innovating in-house. Collaboration is an open and comprehensive process of problem solving, and is especially valuable for organizations whose core is based on changing technology (Huang \& Wilkinson, 2013; Nordman \& Tolstoy, 2014; Sánchez-Navas \& Ferràs- Hernández, 2015). Michelfelder and Kratzer (2013) and Ahuja (2000) affirm that building networks consisting of disconnected or external organizations is the optimal strategy in the long term for organizations. Similarly, Ahuja (2000) explains that success for a company is measured by several elements, including its strategic behavior in regards to innovation, relationships with partners, and its ability to organize its business connections (its network). Network theory shows that a firm's position within a network influences its activities and performance (Ahuja, 2000; Michelfelder \& Kratzer, 2013).

Potential great advantages associated with collaborating with global partners exist: they include cost reductions, quality improvement, and enhanced competitiveness (Thorgren et al., 2012; Wynarczyk et al., 2013), support and risk-sharing to conduct R\&D and commercialization via co-investment, co-marketing, or co-R\&D (Kang, 2012; Wynarczyk et al., 2013; Hossain, 2015).

OI can also stimulate the increase of diversity of technology and minimize gaps between technological innovation and consumer needs (Lichtenthaler, 2011; Hossain, 2015). The presence (of) and interaction with an external network of partners generates support for SMEs to increase their business and technological activities (Ebrahim, Ahmed, \& Taha, 2010; Thorgren et al., 2012). In order to penetrate a global market, firms need to be knowledgeable about its attributes and learn from competitors and partners alike with respect to innovation of technology and services (Narula, 2004). Positive consequences of OI include: 1) benefits of sharing information and knowledge with external sources; 2) the ability to share risk with partners; 3) help to solve problems from partners; 4) a larger amount of 
resources available; and 5) synergies among partners for developing technology and product (Ahuja, 2000; Lawson \& Samson, 2001; Archibugi \& Iammarino, 2002; Narula, 2004; Overby, 2005; Massa \& Testa, 2008; Su et al., 2009; Wincent et al., 2010; Huang \& Yu, 2011; Michelfelder \& Kratzer, 2013; Un \& Asakawa, 2015; Freel \& Robson, 2017; Lin \& Lin, 2016).

However, the superiority of OI over closed innovation appears to be more subtle and should be nuanced.

Although strategic collaboration aims at compensating for insufficiencies or inabilities, certain partnerships can result in excessive use of resources and energy (Todeva \& Knoke, 2005; Lin et al., 2012). For instance, communication and collaboration between external partners can be time consuming and at times an agreement difficult to reach (Ahuja, 2000). These difficulties might explain the low level of success among collaborative activities: $60 \%$ to $70 \%$ of collaborative agreements are terminated without achieving the intended result or goals (Comi \& Eppler, 2009; Cummings \& Holmberg, 2012) as well as the tendency for SMEs to innovate in-house. Additionally, fewer SMEs collaborate with partners for R\&D than large firms, which are more likely to establish global networks all over the world. Other negative consequences exist as well: 1) costly delays; 2) reduction of profit; 3) conflicting goals; 4) short term thinking; 5) overestimated expectations from partners; 6) the absence of any guarantee of success; 7) managing the partners leads to managerial distraction; and 8) dilution of capabilities and competencies.

OI offers benefits but has also costs: a) the cost of coordination to manage relationships and communication; b) the risk of competition and the actions to alleviate this risk; c) the cost of protecting ideas that others can access (Bougrain \& Haudeville, 2002; Todeva \& Knoke, 2005; Adner, 2006; Wincent et al., 2010; Lichtenthaler, 2011; Wynarczyk et al., 2013; Hossain, 2015).

\section{Challenges and Success of Open innovation}

Because of the imbalance of resources between SMEs and larger firms, SMEs put more emphasis on OI during the second phase of innovation, namely commercialization, where they collaborate with large firms. During the first phase (R\&D), they tend to collaborate only with public or nonprofit organizations because they fear losing their technology or creating competitors (Lee et al., 2010). The same authors discuss the intervention of intermediaries within well-constructed and managed networks, to enable a flow of information and strengthening the SME's competitive advantage". Using the example of a South Korean SME, they specify four roles that the intermediary plays to facilitate the SME's innovation: a) research organization and support; b) international structure and support; c) consulting services during collaboration; and d) marketing operations and support (Lee et al., 2010). "The depth and breadth of the information flows impact the innovation for SMEs" (Lee et al., 2010:293).

The selection and management of partners constitute an important element for the success of OI (Un \& Asakawa, 2015). Thorgren et al. (2009) state seven success factors: 1) trust, 2) CEO's support, 3) dedication, 4) capabilities, 5) external relationships, 6) intermediaries, and 7) information technology. Morality and trustworthiness are the most important characteristics to secure partnerships between firms and reliability is a stronger requirement than expertise when a firm considers selecting potential networks or partnerships (Thorgren et al., 2009). Adner (2006) also pointed out that successful innovation requires tracking one's partners and potential adopters as closely as possible. The quality of partnerships is significant for a successful relationship and depends on both economic incentives and mutual trust via active interaction and open communication (Kluyver, 2010). However, finding reliable and appropriate partners overseas and maintaining these partnerships can be overwhelming for firms (Kluyver, 2010).

SMEs have to devote significant resources and effort in developing trust and learning, as well as networking (Lee et al., 2010). 


\section{RESEARCH}

\section{Overview}

We implement a qualitative approach on several SMEs implementing an innovation strategy in a South Korean context to explore and understand the determinants and drivers of globalization related to OI for these firms.

The choice of a case study was motivated by the notion that qualitative perspective enables a better understanding of phenomena which scope and content are difficult to examine because not well defined or stabilized. A case study methodology is better suited to explore the 'why' and 'how' (Eisenhardt, 1989; Chiaroni et al., 2011; Kang, 2012). This research tradition was implemented by several scholars (Chesbrough, 2003; Thorgren et al., 2012; Henttonen, 2013).

\section{Context and Object of Research}

Since the restructuring of advanced economies in the 1970s and 1980s, SMEs are increasingly viewed as the vital source of product development innovations and new technologies (Thorgren et al., 2012). SMEs are defined by a number of factors and criteria, such as size, structure, number of employees, sales volume, and ownership (Van de Vrande et al., 2009; Ebrahim et al., 2010; Thorgren et al., 2012; Nordman \& Tolstoy, 2016; Francioni et al., 2015; Wikhamn \& Styhre, 2016).

The definition varies with the country. In South Korea, a SME is an independent organization that employs fewer than 300 employees. SMEs account for $99 \%$ of South Korean company's number.

SMEs enjoy several advantages: 1) they can react quickly to changes in the marketplace, as opposed as multinational and large firms which take more time to make decisions; 2) SMEs have a simple and short hierarchical line that enables to take risk and make decisions quickly (Hossain, 2015; Freel \& Robson, 2016).

However, SME also experience disadvantages: 1) a lack of resources; 2) insufficient information about market opportunities; 3) a lack of knowledge about the process of technological innovation; 4) the absence of benefits from a large network overseas; 5) a lack of infrastructure; and 6) a lack of financial resources (Edwards, Delbridge, \& Munday, 2005; Van de Vrande et al., 2009; Lee et al., 2010; Rosenbusch et al., 2011; Thorgren et al., 2012; Henttonen, 2013; Hossain, 2015; Wikhamn \& Styhre, 2016).

Consequently, SMEs do not generally have enough confidence in global markets opportunities and are reluctant to pursue them. Moreover, SMEs have shown limited efforts to overcome these drawbacks. SMEs are under pressure to sustain their competitiveness in domestic as well as global markets because of their characteristics and limitations.

SMEs have the greatest positive impact via innovation when collaborating with different types of partners. In general, large firms are more likely to conduct structured innovation processes and have more focused networks and long-term goals (Thorgren et al., 2012). Contrastively, SMEs tend to be more focused on immediate projects and short-term rather than long-term goals as they need consistent revenue to organize all expenses. Overall, SMEs are clearly different from their larger counterparts in regard to elements such as R\&D activities, marketing strategy, or technological capabilities. This fact reinforces the interest of studying SMEs separately from large firms.

Recently, South Korean domestically oriented SMEs have put more emphasis on penetrating overseas markets to achieve a trade target of \$2tn, a preoccupation shared by the South Korean government. South Korean SMEs governmental support is considered as a priority (Rhee et al., 2010). The extensive government support enhances South Korean SME's growth potential and ability to achieve successful globalization.

According to Bloomberg's annual ranking of the most innovative countries in the world, South Korea was ranked first. It has one of the highest levels of gross domestic expenditure for R\&D (Pro Innovation Europe, 2012). South Korean SMEs have been called the "Asian miracle" that continues to be the most intriguing and the least understood fact of the region's fast-growing economies. 
This fact constitutes a specificity of the South Korean economy that motivates us to examine South Korean SMEs as the backbone of the economy and their role in terms of innovation (OECD, 2002; Bae and Yu, 2005; SMBA Commissioned Report, 2006; Park, 2010). Noticeable strengths of South Korean SMEs are strong consensus for governmental support and increasing investments in science and technology for economic growth (McKinsey Korea, 2014). South Korean SMEs exhibit specific attributes related to innovation: a) producing dynamic technologies, b) operating in fast moving technological industries, c) benefiting from various advanced government policies and supportive programs for firms. South Korean SMEs and the government are focused on innovation but also on globalization of the country economy.

For most companies, difficulties and uncertainties in global markets lead them to hesitate to penetrate these markets (Ebrahim et al., 2010; Santamaria \& Surroca, 2011; Tsou, Cheng, \& Hsu, 2015). South Korean SMEs are likely to seek global markets penetration because of their limited domestic market. However, globalization represents for them a great challenge as well; for example the difficulty for these SMEs to manage effectively the barriers to globalization (Zain \& $\mathrm{Ng}, 2006$ ).

\section{Data Collection}

The research involved 14 South Korean SMEs and took place between 2014 and 2016. The researcher used a three-pronged methodology to collect material about the studied phenomenon. Strategic networks have been defined as "intentionally formed groups of SMEs in which firms: (1) are geographically proximate, (2) operate within the same industry, potentially sharing inputs and outputs, and (3) undertake direct interactions with each other for specific business outcomes (Thorgren et al., 2009). Thus, we have selected firms which are in the same high-tech industry in South Korea and which collaborate with local and global partners. A list of the 14 SMEs is presented in Table 1, Sample of South Korean SMEs.

First, the researcher collected data about the firms to understand the context and the industries. Because of his involvement in these firms as a consultant, the researcher possesses an in-depth knowledge of these companies (corporate history; CEO's message and philosophy; management style; corporate culture; and business model). The presence and connection with the companies equipped the researcher to observe the behaviors and opinions of the interviewees even outside the research setting.

Second, the researcher collected material from the companies' production of reports, advertising material, online content, etc.

Third, the researcher interviewed 24 individuals with managerial responsibilities in these 14 companies, mostly CEO, directors, and managers. These interviews generated knowledge about the OI types used by the companies; each company belonged to one type of OI based on the two dimensions: Open vs. Closed; and Domestic vs. Global. These two dimensions generate a matrix with four quadrants with only three active quadrants (when innovation is closed, the two quadrants are joined and form only one quadrant called Close Innovation; distinguishing between Global and Local is irrelevant in that case). This grid is provided in Table 2, Modalities of innovation.

Six companies used an Open/Global mode; four used an Open/Local mode, and four used a Closed mode. Each of these three situations was investigated with a specific questionnaire. Most of the interviews were conducted face-to-face, or digitally using Skype for between half an hour to an hour in an audio tape format. Besides this recording, the researcher took notes in order to collect all the information needed. Some firms were interviewed multiple times. In this case, additional interviews were conducted by phone, email, or SMS.

Triangulation of methods was applied to improve reliability and validity (i.e. observations, documents, and interviews).

\section{Data Processing}

The collected material was embedded into a monograph (Eisenhardt, 1989) to synthesize all the events, focusing on the relationships between the collaboration modes of OI and the process of globalization. 
Several theories were used to examine the innovation process. Because of space constraints, these theories could not be developed in this paper but are only mentioned: the innovation theory developed by Freel \& Robson (2016) as well as Wikhamn \& Styhre (2016) that explains the firm's innovation process.

To explore the globalization strategy, the theory of Generic Global Strategy (Kluyver, 2010), and of the Global Strategy (Zou \& Cavusgil, 1996; Laanti, Gabrielsson, \& Gabrielsson, 2007) were mobilized. A key tenet to these approaches is the contingency of organizational performance based on the type of global strategy chosen by the firm.

The data from the interviews, which constitutes the core of the collected material, was translated from Korean to English. The English translation was analyzed, using a theoretical framework whose design is described below.

To help extract valuable elements from the collected material, we used a grid of analysis which covers a list of variables borrowed from the classic strategic models. These variables cover the area of external strategy (relations of organization with its environment), and the internal strategy that encompasses all the internal components of a firm. This framework was first built and then evolved once the data analysis took place to better reflect the collected material. A synthesis of this grid is provided in Table 3, Strategic frame of empirical analysis (simplified). 


\begin{tabular}{|c|c|c|c|c|c|c|c|c|c|c|c|c|c|c|c|}
\hline \multirow{10}{*}{ 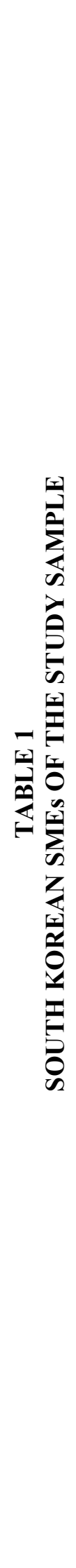 } & 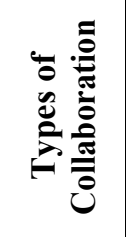 & $\begin{array}{l}\bar{\pi} \\
0 \\
0 \\
0 \\
\infty \\
\tilde{0} \\
\tilde{0} \\
0\end{array}$ & $\begin{array}{l}\bar{\pi} \\
0 \\
0 \\
0 \\
\infty \\
\tilde{0} \\
0\end{array}$ & $\begin{array}{l}\overline{0} \\
0 \\
0 \\
0 \\
\infty \\
\tilde{0} \\
0 \\
0\end{array}$ & $\begin{array}{l}\overline{0} \\
0 \\
0 \\
0 \\
2 \\
\overline{0} \\
\tilde{0}\end{array}$ & 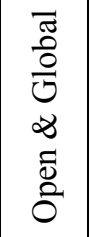 & $\begin{array}{l}\bar{\pi} \\
0 \\
0 \\
0 \\
0 \\
0 \\
0 \\
0\end{array}$ & 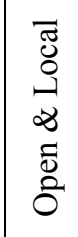 & $\begin{array}{l}\bar{\Xi} \\
0 \\
0 \\
2 \\
\tilde{\Xi} \\
\tilde{0}\end{array}$ & $\begin{array}{l}\overline{0} \\
0 \\
0 \\
\infty \\
\bar{ల} \\
0 \\
0\end{array}$ & 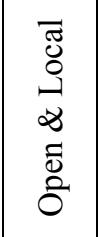 & $\begin{array}{l}\vec{D} \\
\dot{0} \\
0 \\
0 \\
0\end{array}$ & $\begin{array}{l}\bar{D} \\
\mathbb{0} \\
0 \\
\bar{U}\end{array}$ & $\begin{array}{l}\overrightarrow{0} \\
\mathbb{0} \\
0 \\
0 \\
0\end{array}$ & $\begin{array}{l}\bar{D} \\
0 \\
0 \\
0 \\
\end{array}$ \\
\hline & 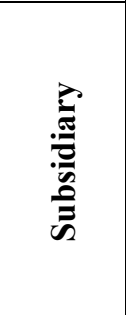 & 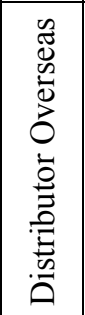 & 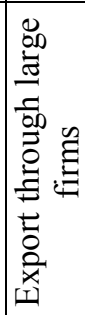 & 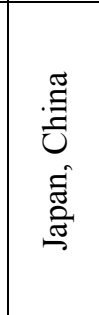 & 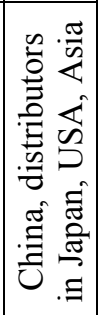 & 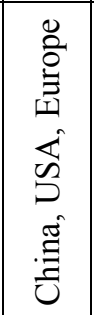 & 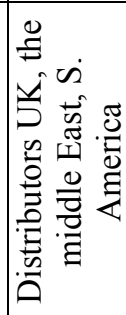 & 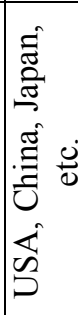 & 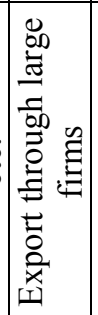 & 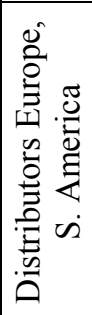 & 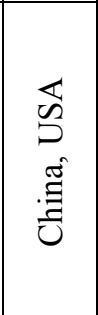 & 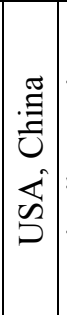 & 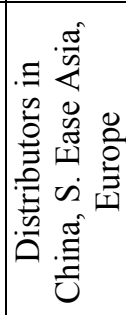 & 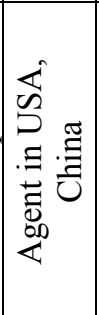 & 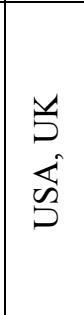 \\
\hline & 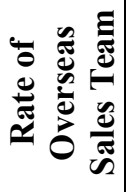 & 仓ें & $\stackrel{\circ}{\beth}$ & @̊ & ì & $\stackrel{\circ}{\dot{\nabla}}$ & î̀ & ठें & $\stackrel{\circ}{0}$ & ஓें & ஓें & 吕 & 仓ें & ஓें & $\stackrel{\stackrel{\circ}{ \pm}}{ }$ \\
\hline & 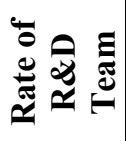 & 仓ें & 吕 & ᄋें & $\stackrel{\partial}{\partial}$ & $\stackrel{\circ}{\infty}$ & ठి̊ & in & 官 & ठి & $\stackrel{\circ}{0}$ & 号 & 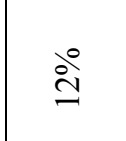 & 8ें & ठें \\
\hline & 离 & ఏें & $\stackrel{\stackrel{0}{\gamma}}{\stackrel{\gamma}{\sigma}}$ & 离 & 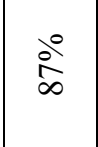 & ठ̊ㅇ & छे & iे & ठें & छे & o̊ & 字 & iें & 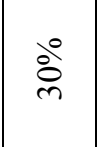 & ठ̊ㅇ \\
\hline & 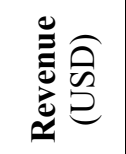 & $\underset{\Xi}{\ddagger}$ & $\underset{\Omega}{\Sigma}$ & $\sum_{\sigma}$ & $\sum_{\infty}$ & 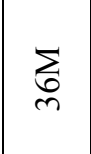 & $\sum_{n}$ & $\sum_{\Omega}$ & $\sum$ & $\sum_{m}$ & $\sum_{0}$ & 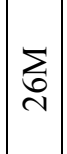 & 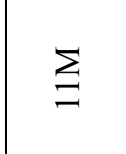 & $\sum_{\forall}$ & 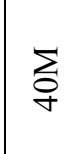 \\
\hline & $\begin{array}{l}\ddot{0} \stackrel{0}{\bar{a}} \\
\dot{0} \ddot{0}\end{array}$ & in & $\hat{\sigma}$ & in & ৪্ণ & $\stackrel{\circ}{\sim}$ & ळ & $\underset{\sim}{\widetilde{N}}$ & $\bar{n}$ & F & $\stackrel{\infty}{\stackrel{\text { సे }}{ }}$ & $\stackrel{ }{\sim}$ & $\tilde{n}$ & ก & $\widehat{\Xi}$ \\
\hline & 它 & 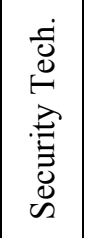 & 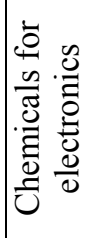 & 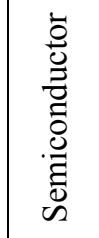 & 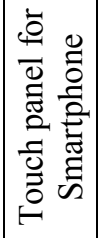 & $\begin{array}{l}z \\
u \\
u \\
\geq 2 \\
>\end{array}$ & $\begin{array}{l}x \\
0 \\
0 \\
0 \\
\frac{0}{1} \\
\frac{1}{\omega} \\
\tilde{n}\end{array}$ & 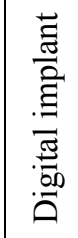 & 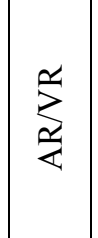 & 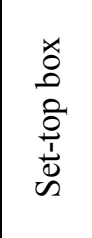 & 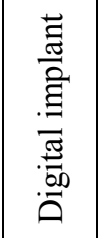 & 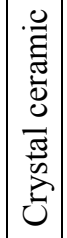 & 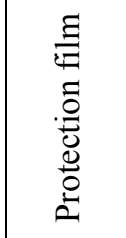 & 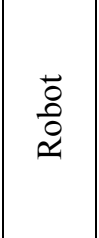 & 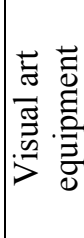 \\
\hline & 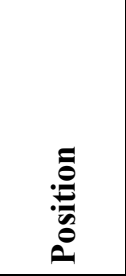 & 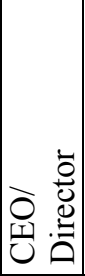 & $\begin{array}{l}0 \\
\text { 至 }\end{array}$ & 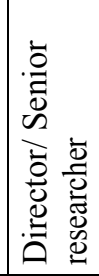 & 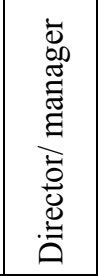 & 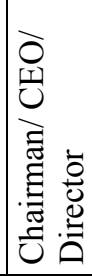 & 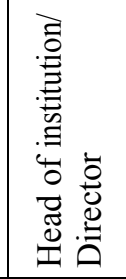 & 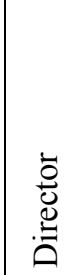 & 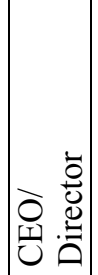 & 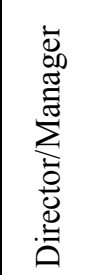 & 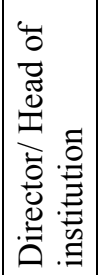 & 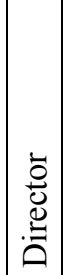 & 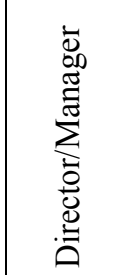 & 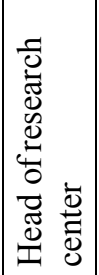 & 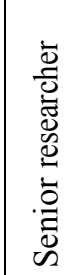 \\
\hline & 踣 & $\bar{\lambda}$ & $\sum$ & 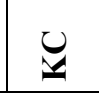 & $\bar{\Omega}$ & $\sum$ & $\bar{Z}$ & 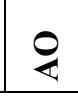 & 4 & $\infty$ & $\sum_{0}^{2}$ & Z & s) & $\frac{x}{\Sigma}$ & Z \\
\hline
\end{tabular}

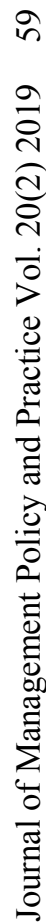


TABLE 2

MODALITIES OF INNOVATION

\begin{tabular}{|c|l|l|}
\hline Scope & \multicolumn{1}{|c|}{ Closed Innovation } & \multicolumn{1}{c|}{ Open Innovation } \\
\hline Domestic & $\begin{array}{l}\text { Firms only develop innovation } \\
\text { inside their own boundaries and } \\
\text { do not involve external partners }\end{array}$ & $\begin{array}{l}\text { Firms develop innovation in a } \\
\text { process that involves various } \\
\text { categories of domestic partners }\end{array}$ \\
\hline Global & $\begin{array}{l}\text { Firms only develop innovation } \\
\text { inside their own } \\
\text { boundaries and do not involve } \\
\text { external partners }\end{array}$ & $\begin{array}{l}\text { Firms develop innovation in a } \\
\text { process that involves various } \\
\text { categories of domestic partners } \\
\text { and of international partners }\end{array}$ \\
\hline
\end{tabular}

TABLE 3

STRATEGIC FRAME OF EMPIRICAL ANALYSIS (SIMPLIFIED)

\begin{tabular}{|l|l|}
\hline External strategy variables & Internal strategy variables \\
\hline Market Competition Technology & Market orientation Partnership \\
& orientation Management styles \\
& Organizational culture \\
& Organizational capabilities Global \\
& mindset \\
& Global experience \\
\hline
\end{tabular}

These variables are used to describe how the phenomenon is unfolding in a narrower and easier way thanks to categories.

The analysis of the collected material was based on the use of text analysis methodology (NVIVO) that codes the material and extracts nested meaning categories explored at various levels of aggregation. The frequency of citations is used in these methodologies. The researcher has first used the coding emerging from the text analysis in an inductive approach to identify the relevant themes. Then, these themes were compared with the primary list of codes and revised. The exploration guiding idea was to search for the drivers and consequences of the process of OI and globalization. We use the frequency of the codes related to our theme to examine the phenomenon.

Because the cases were sorted into the three categories of modalities of OI, their comparison offers great insights into the drivers and the consequences of these three innovation options.

\section{FINDINGS AND IMPLICATIONS}

We will discuss in the following sections various types of findings and recommendations: 1) the exploration of the three approaches or categories related to the mode of Innovation; 2) the process of innovation itself; 3) the choice of an OI model; 4) the implications for managers; 5) a model of OI design; and 6) some propositions for future research.

\section{The Three Categories of Open Innovation}

In this paper, we used a typology of the innovation modes based on the two dimensions of Openness and Global/Local dimensions. This typology enables us to analyze how firms benefit in these various situations in order to successfully globalize (Enkel et al., 2009).

We first discuss these three categories of OI. 


\section{Closed Innovation}

In this situation, SMEs do not search any partners for innovation and develop innovation by themselves since they have in-house innovative capabilities. They are generally vulnerable to a change in market and must commercialize these innovations.

These SMEs consider that their technology is at the highest international level of sophistication and strongly desire to protect it; this willingness and fear of compromising their technology bare them from collaboration and from sharing their technology. These SMEs own the necessary skills to expand into global markets using their own channels of distribution such as agents and/or subsidiaries. However, the firms located in suburban areas acknowledge the difficulty to hire talents in marketing who have an international sensibility and experience.

\section{Open Local Innovation}

The firms in this category experience a lack of capabilities, market information and financial resources to implement a successful R\&D. Most of them rely on the South Korean government's support with direct funding or collaboration with universities and other institutions. These firms use piggybacking, the mobilization of resources from other companies to achieve a goal, -in this case selling and distributing via multinationals' market channels to export indirectly-. They accept to provide their technology to these large multinationals that become partners. The SMEs in the Open Local Innovation category behave in a relatively non aggressive and enthusiastic way to conquer new markets abroad and to find global partners. They are reluctant to make the investment for the exploration of opportunities abroad and to cover the transaction costs to establish international partnerships. They prefer to work with local partners, an easier and less risky venture. Although these firms do not close the door for open global innovation in the future, they accept to forego some profitability in exchange for a safer route to internationalization.

\section{Open Global Innovation}

Relatively few South Korean firms belong to this third category. These firms work with foreign partners, generally in the same value chain (e.g. suppliers or distributors). These partners suggest ideas and serve as a feedback tool to take the market's pulse about new trends.

This collaboration does not go without drawbacks. First, this mode of collaboration proves expensive since SMEs has to invest in all the transactions costs required to build connections, to deal with complex managerial, cultural, and technical issues. Second, because SMEs open up their innovative activities to a partner, a substantial risk of accidental disclosure by the partner of patent or other protected proprietary information exists. If this risk materializes, it could seriously damage these SMEs' competitive advantage (Wynarczyk et al., 2013; Alexy, Bascavusoglu-Moreau, \& Salter, 2016). Third, although SMEs are capable of globalizing the technologies, achieving a profit quickly requires a longer horizon perspective and some patience.

The interviews show that a key driver of globalization lies in the enthusiasm or will of the decision makers for internationalization. If they want it, they make it happen. A driver of a successful partnership is the existence of economic incentives to do so. If a partnership brings in money, it is more likely to be sustainable over a long period of time. 


\section{The Process of Open Innovation}

Contrarily to large firms, most SMEs collaborate in the later phase of the innovation process, e.g. in the commercialization and/or marketing stages. However, firms could benefit from collaboration at the early stage of collaboration which is R\&D. The partners who collaborate for R\&D can be an appropriate partner for marketing and manufacturing as well. Firms can develop technology up to date through their $R \& D$ partners and utilize their global channels. Knowledge and information is a crucial issue for firms to innovate and to have competitive power around the world.

Use and reliance on networks can be either constructive or destructive. Therefore, the use of OI does not constitute a panacea for all companies. A careful analysis must take place to understand the characteristics of the focal SME and determine if OI is a good fit.

The literature insists on the effort required from the company implementing OI to be successful in this endeavor. Zynga et al. (2018) use three perspectives to consider OI implementation: a) the problemsolving perspective that looks at ways to solve challenges; $b$ ) the organizational change perspective; and c) the micro-foundations perspective that identifies capabilities to develop successful innovation. Their research based on a large number of firms concludes that to ensure success in innovation, actions must be taken at the level of the individual, the organizational structure, and the innovation process itself (Zynga et al., 2018).

For example, a certain level of in-house competence must be maintained to secure a firm's core technology and minimize complexities and risks caused by collaborating with partners (Owen \& Yawson, 2015). SMEs must be careful when collaborating with large companies which have resources and financial power. A collaboration with a firm within the same industry increases the chances for innovation through collaboration, but may also increase the challenges of assets protection.

However, collaborating with firms with complementary capabilities leads to a better outcome for innovation than firms with similar capabilities which entails a greater risk of rivalry. If SMEs work in a complementary perspective, they will likely be more incline to mutual respect and genuine cooperation, because they need each other. SMEs should have a large enough network to search and select their potential partners from, and to devote enough resources in the diligence process of "courting" their future partner.

Collaborating in an OI frame may imply foreign SMEs and not just domestic firms. This opens the entire box of the geographic differences and attributes management, to be able to actually understand and work within other political, technical, cultural, and economic systems. To increase the success rate of global partnerships, firms can build a joint-institution to cooperate in the same space until the project is done. This minimizes the risks inherent to global partnerships and enables a mutual real-time communication. A structural and a physical space in common reinforces the intention of collaboration and signals to the stakeholders a strong will to collaborate for the betterment of both partners. Understanding how to utilize OI for successful globalization constitutes a positive driver for success for example through benchmarking firms' strategies described in success stories or in case studies.

Companies benefit from both local and global partnership; a SME which has a very strong technology and plenty of R\&D resources may not need local nor global partnership. But because this situation appears relatively unusual for SMEs, we can conclude than in general OI is a positive tool for development.

If SMEs fail their cooperation, they feel isolated and the negative experience might keep them for trying again for a while. Time to market will most likely be delayed and firms may lose their potential markets to their competitors.

Depending on firms' decision of global strategies and their circumstances, firms can select the collaboration mode that is most appropriate for them aiming to globalize: Closed, Open \& Local, or Open \& Global R\&D. 


\section{Choosing the Innovation Model}

We attempt to recommend which combination of SMEs' attributes constitute a fit for the various innovation modalities (Open \& Global, Open \& Local, or Closed R\&D targeting international markets).

OI performance is impacted by many factors, but key factors are: SME technical ability; SME absorptive capacity; the quality of technology transfer; the allocation of time in the process; and the managerial attention to OI. The overall components of the political, economic, and cultural environment play an important role as well (Zhao, Sun, and $\mathrm{Xu}, 2016)$.

We propose a Grid of fit with the Innovation model that is based on the comparison of a set of internal and external variables and the type of innovation model that seems to be a good fit for the SME. This table is constituted of three innovation modes in columns and of variables in lines. At the intersection the manager can search for the description which is the closest to the focal SME situation. This grid is presented in Tables 4 and 5, the Innovation model fit grid.

\section{TABLE 4 \\ INNOVATION MODEL FIT GRID}

\begin{tabular}{|c|c|c|c|}
\hline Elements & Closed Innovation & Open Local Innovation & Open Global Innovation \\
\hline $\begin{array}{l}\text { Current globalization } \\
\text { International sales } \\
\text { Position in globalization } \\
\text { process } \\
\text { Experience of partnership } \\
\text { management } \\
\text { International experience with } \\
\text { partners (number; intensity } \\
\text { and duration) } \\
\text { Existence of procedures } \\
\text { Technology } \\
\text { Complexity } \\
\text { Ease to protect } \\
\text { Level imitability and replication } \\
\text { Competition } \\
\text { Rivals' willingness and } \\
\text { capabilities to innovate and to } \\
\text { steal/replicate technology }\end{array}$ & $\begin{array}{l}\text { Small portion of } \\
\text { international sales } \\
\text { Early stage of } \\
\text { globalization } \\
\text { Limited or absence of } \\
\text { partnership } \\
\text { management } \\
\text { Not complex and/or } \\
\text { difficult to protect } \\
\text { because easily imitable } \\
\text { or replicable; considered } \\
\text { as top level technology } \\
\text { Intense rivalry } \\
\text { Rivals want to capture } \\
\text { technology and have } \\
\text { capabilities to do so }\end{array}$ & $\begin{array}{l}\text { Medium portion of } \\
\text { international sales } \\
\text { Some international experience } \\
\text { Significant partnership } \\
\text { management experience and } \\
\text { knowledge measured by past } \\
\text { cooperation and explicit } \\
\text { procedures and knowledge } \\
\text { At least complex or } \\
\text { difficult to imitate because } \\
\text { of intrinsic attributes or } \\
\text { other protection } \\
\text { Strong rivalry } \\
\text { Rivals want to capture } \\
\text { technology but aim at } \\
\text { international and could } \\
\text { cooperate }\end{array}$ & $\begin{array}{l}\text { Significant portion of } \\
\text { international sales } \\
\text { Solid international experience } \\
\text { Strong partnership } \\
\text { management experience } \\
\text { and knowledge measured } \\
\text { by past cooperation and } \\
\text { explicit procedures and } \\
\text { knowledge } \\
\text { At least complex or } \\
\text { difficult to imitate because } \\
\text { of intrinsic attributes or } \\
\text { other protection } \\
\text { Usual rivalry } \\
\text { Rivals are domestic and } \\
\text { global so using OI enables } \\
\text { to capture the positive } \\
\text { effects of collaboration }\end{array}$ \\
\hline
\end{tabular}




\section{TABLE 5 \\ INNOVATION MODEL FIT GRID}

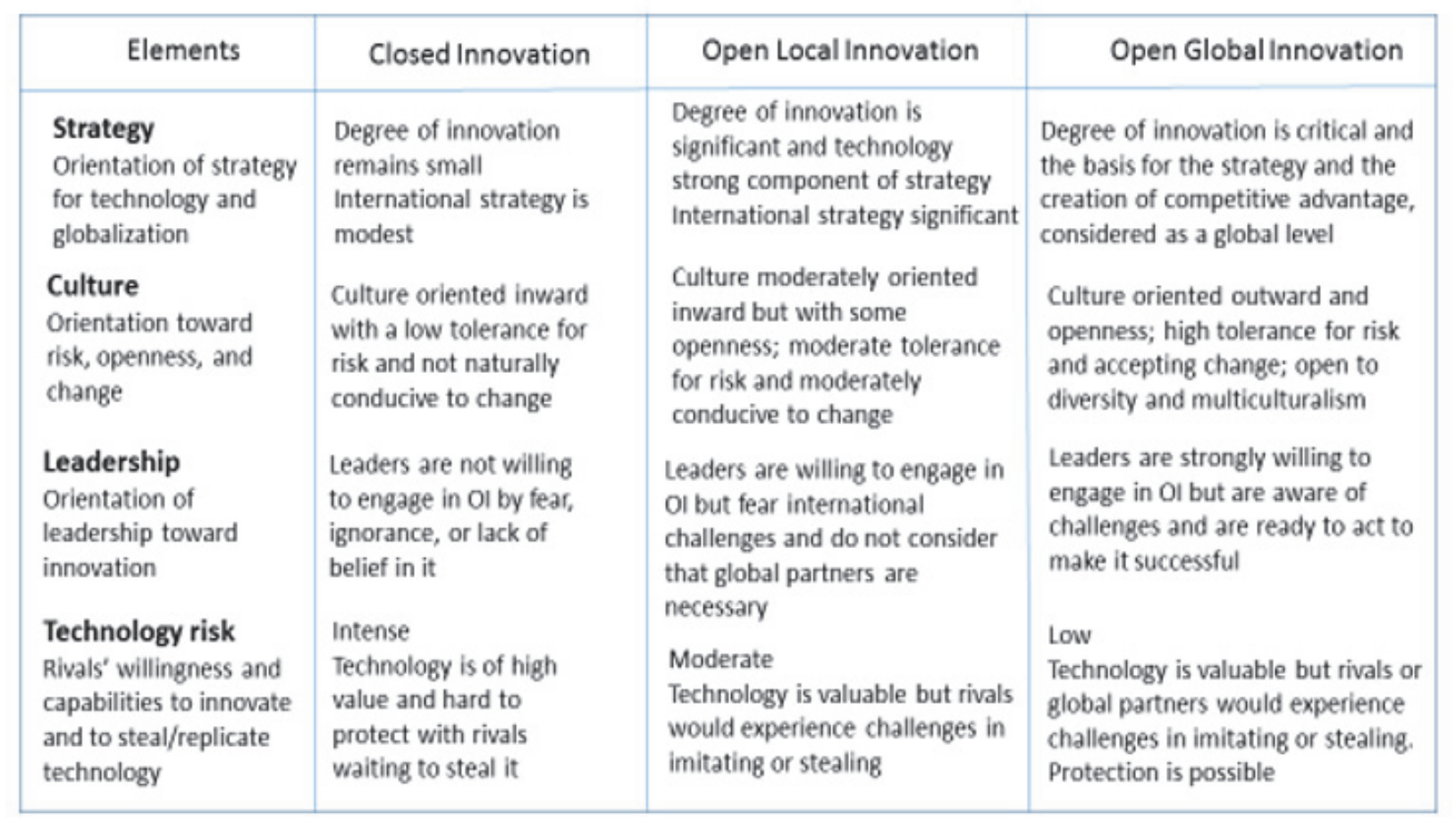

This grid should be used more as a managerial guide than a theoretical description of ideal-types of innovation models. It is likely that some situations will borrow content belonging to several innovation models. Therefore, the manager should use acumen and logic to determine which dimension (rowa) has the strongest weight in the decision. These dimensions are not obligatorily equal and must be used as needed and in perspective of the specifics of the situation.

\section{Implications for Managers}

Beyond the Innovation model Fit Grid, several topics of importance are highlighted. First SME are not isolated but are part of an eco-system which can foster co-creation and economic progress not only at the industry level but for the entire economies (Bogers et al., 2018). The OI goes beyond the meso-level of industry and involves a larger set of actors to reduce uncertainties, to promote connections between science and innovation, and to regulate innovation.

Second, the OI phenomenon cannot be analyzed only from a technical standpoint. This tendency is observed in SMEs which focus on technology and consider only the "hard variables" of the equation. A larger perception of the phenomenon is necessary and change at the organization scale might be necessary to undertake to transform the firm in a way that it becomes successful in its OI operations (Zynga et al., 2018).

Third, an organization's business model that denotes the organization's core logic to creating and capturing value is also impacted by OI. OI requires an alignment of all the components of the business model (namely the content of activities, the structure of activities, and the governance of transactions) (Saebi \& Foss, 2015) with the innovation activity. This alignment implies the involvement of the highest level of the organization outside of the technical area who should be aware of the necessity of the larger perspective.

Fourth, it appears that some dimensions of OI are important and are not explored in the study: 1) mode of openness or the OI mode; 2) the degree of openness measured by the extent of the cooperation (number and diversity of partners) and the intensity of the cooperation (duration and volume of the 
knowledge and ideas flowing inbound and outbound); 3) the depth of knowledge searched defined as the intensity of collaboration of the partners, indicated by their involvement in the process; 4) the breadth of knowledge searched defined as the diversity of external partners involved in the OI; 5) a flow working inbound, outbound, or in an integrated way (Bogers et al., 2018; Zhao, Sun, \& Xu, 2016; Saebi \& Foss, 2015). Felin and Zenger (2014:918) structure several modes of OI based on a matrix mixing the complexity of the technical issue and the difficulty to get the knowledge to solve the issue (called "hidden knowledge dimension"). They associate various modes of OI to the quadrants of the matrix. These OI modes are based on the number of partners and the intensity of the relationship. These dimensions, although beyond the scope of our research, are needed to determine which model of innovation is the best. They should be in the background of managers' evaluation and decisions and require additional research.

Fifth, the nature of the OI itself constitutes a complex object of study. There is not only one or two OI components, but many of them that authors have tried to list and to structure within categories. For example, Mina et al. (2014) suggest a typology with formal and informal OI activities which encompass a collaboration with at least an external actor.

Sixth, the type of partners the SME is connecting with is of utmost importance. All partners are not created equal. Zeng, Tie, and Tam (2010) highlight three categories of partners: a) Vertical partners with customers, suppliers, producers, service providers, and competitors; b) Horizontal partners with intermediaries in technologies, financial training, venture capitalists, technology transfer institutions; and c) Lateral partners with research universities, technical institutes, and research institutions.

Seventh, the differences between the types of partners should be analyzed by SMEs' managers who understand the expectations, power, desire to cooperate, and complementarity of skills and capabilities of their potential partners. To implement such an analysis, analytical grids for stakeholders can be useful, because they cover the entire spectrum of what the SMEs need to know. A dimension might be added: what power of idea generation does the potential partner possess?

Eighth, the mode of OI is connected with the type of partners the SMEs are searching for. Notably, firms use open modalities in sequence, in a way similar to the modes of internationalization (first exportation, then production, etc.). The analysis of each of the possible modes of OI would help managers to choose the modality that best fits their situation (Van de Vrande et al., 2009).

Ninth, the motivation for OI constitutes another critical element on which managers should spend time. According to Van de Vrande et al. (2009), the most important motives for OI are market related; SMEs want to keep up with their market development and to meet their clients demand. Barriers exist in different flavors but always encompass cultural, organizational, and cognitive aspects on top of the classic barriers associated with SMEs (lack of resources, problems with contracts) and with alliances (free riders in cooperation, conflicts between partners). Many issues relate to the cultural and organizational aspects of the firm, the "soft" variables when compared to technology. Additionally, each type of OI mode leads to specific problems in addition to these generic issues, generated by the nature of the partner and the relationship. These is a strong need to clearly associate all the variables to be able to get a complete picture of all the elements of the puzzle. This topic is in coherence with Zobel and Hagedoorn (2018) who open the black box of the organization itself as both a consequence of OI and a requirement for success. They show the impact of OI on the power structure of the firm, its identity, its structure of competencies, and the boundaries of the organization.

\section{Designing the Innovation Model}

Finally, we propose a model which is a strategic and methodological guide to help managers navigate the design of the innovation model, presented in Figure I, the Open Innovation model Design. 


\section{FIGURE 1 \\ OPEN INNOVATION MODEL DESIGN}

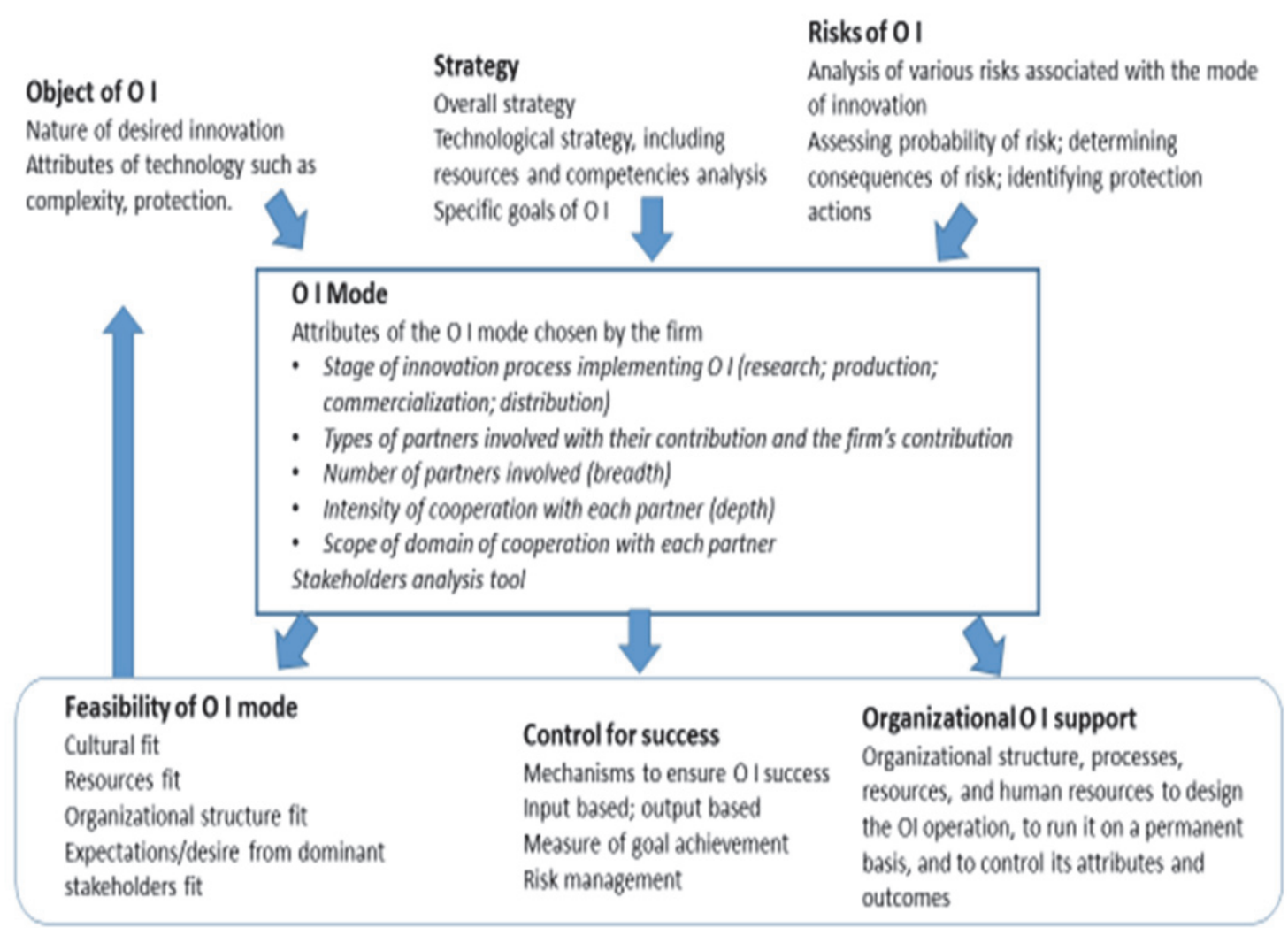

This model, inspired from the strategic management process, examines all the variables in a processual way so decision makers can analyze the firm's strategy, environment, and internal situation in a systematic and organized way. This model emphasizes the importance of the goals of the firm and their connection to the OI models. OI is a tool at the service of a higher level objective and should not be implemented just for its own sake, without a thorough analysis of the goal, antecedents, and consequences of such a choice.

This model contributes to highlight the important variables that must be considered. It also includes the mechanisms to support the OI activity within a larger organization, which proves to be of great importance for success.

\section{Future Studies}

Future studies could examine more in depth how different phases of OI activities (such as the R\&D and the commercialization phases) impact a firm's successful globalization.

Understanding how government policies and subsidy programs influence firm's decision of collaboration mode for innovation would be interesting, especially in countries where the government intervenes significantly in this area.

Understanding the role of a specific category of actors in the OI system, the so-called intermediaries that provide various services to SMEs (Da Silva, Howells, \& Meyer, 2018). Their role is likely to increase because of the development of the economy intermediation component.

The construct of OI is central but needs to be analyzed according to dimensions to get a better understanding of the phenomenon. These dimensions could be studied to explore which modes of OI are associated with performance depending on contextual variables. Felin and Zenger (2014) called for a 
more fine-grained, nuanced, and normative approach to understand the phenomenon at a micro level: this will help decision-makers to connect with real managerial situations.

Context matters; this statement implies that OI should be studied in various contexts, including technologies; industries; intellectual property regimes; business infrastructure; and various cultures (Dahlander \& Gann, 2010). How do other cultural contexts impact SMEs' innovative behavior? This would need additional research and the specific input of the cultural effect of innovation.

\section{CONCLUSION}

At a time where globalization is here to stay and where the environment situation provides incentives to SME to use OI, this topic is more than ever valuable and deserves our attention. Open innovation is becoming more and more important for SMEs to promote their innovative capabilities and manage their markets: its use is growing. This phenomenon constitutes a response to the insecurities of the current environment but also to the barriers to innovation specifically experienced by SMEs (Zeng, Tie, \& Tam, 2010). Open innovation sees its popularity increase (Van de Vrande et al., 2009).

Our study shows the importance of OI in SMEs' strategic arsenal. Our empirical study has highlighted the various behaviors of SMEs in regard to OI and understood their motivations to do so. It has also shown three vary different approaches to innovation.

The various modalities of OI should be carefully understood and assessed, since they have advantages and disadvantages. We provide a grid of analysis for the fit between the SME's specific situation and a strategic guide to navigate the design, implementation, and control of open innovation. Open innovation constitutes an important topic that can be a matter of survival and success forSMEs. 


\section{REFERENCES}

Abell, D. (2014). The Past, Present, and Future of Strategy: Broadening Challenges; Advancing Insight. Revista Ibero-Americana de Estratégia, 13(03), 07-18.

Achrol, R. S. (1996). Changes in the Theory of Interorganizational Relations in Marketing: Toward a Network Paradigm. Journal of the Academy of Marketing Science, 25(1), 56-71.

Adner, R. (2006). Match Your Innovation Strategy to Your Innovation Ecosystem. Harvard Business Review, 84(4), 98-107.

Adner, R., \& Kapoor, R. (2010). Value creation in innovation ecosystems: how the structure of technological interdependence affects firm performance in new technology generations. Strategic Management Journal, 31(3), 306-333.

Agarwal, R., Croson, R., \& Mahoney, J. (2013). The role of incentives and communication in strategic alliance: an experimental investigation. Strategic Management Journal, 31(4), 413-437.

Ahuja, G. (2000). Collaboration Networks, Structural Holes, and Innovation: A Longitudinal Study. Administrative Science Quarterly, 45(3), 425-455.

Ale Ebrahim, N., Rashid, S. H. A., Ahmed, S., \& Taha, Z. (2011). The effectiveness of virtual R\&D teams in SMEs: Experiences of Malaysian SMEs. Iems, 10(2), 109-114.

Alexy, O., Bascavusoglu-Moreau, E., \& Salter, A. J. (2016). Toward a behavioral theory of open innovation. Industrial and Corporate Change, 25(2), 289-306.

Archibugi, D., \& Iammarino, S. (2002). The globalization of technological innovation: definition and evidence. Review of International Political Economy, 9(1), 98-122.

Asmussen, C. G., Pedersen, T., \& Petersen, B. (2007). How Do We Capture "Global Specialization" When Measuring Firms' Degree of Globalization? Management International Review, 47(6), 791-813.

Axelrod, R. (2000). On Six Advances in Cooperation Theory. Analysis \& Kritik, 22(1), 130-151.

Backer, K. D., López-Bassols, V., \& Martinez, C. (2008). Open innovation in a global perspective: what do existing data tell us? OECD Science, Technology and Industry Working Papers, No. 2008/04, OECD Publishing.

Baregheh, A., Rowley, J., \& Sambrook, S. (2009). Towards a multidisciplinary definition of innovation. Management Decision, 47(8), 1323-1339.

Belderbos, R., Carree, M., \& Lokshin, B. (2006). Complementarity in R \& D Cooperation Strategies. Review of Industrial Organization, 28(4), 401-426.

Bierly, P. E., \& Gallagher, S. (2007). Explaining Alliance Partner Selection: Fit, Trust and Strategic Expediency. Long Range Planning, 40(2), 134-153.

Bogers, M., Chesbrough, H., \& Moedas, C. (2018). Open innovation: research, practices, and policies. California Management Review, 60(2), 5-16.

Bougrain, F., \& Haudeville, B. (2002). Innovation, Collaboration and SMEs Internal Research Capacities. Research Policy, 31(5), 735-747.

Boutinot, A., \& Mangematin, V. (2013). Surfing on institutions: When temporary actors in organizational fields respond to institutional pressures. European Management Journal, 31(6), 626-641.

Brickley, J. \& Smith J. Z. J., (2000). An Introduction to Game Theory and business strategy. Journal of Applied Corporate Finance, 13(2), 84-98.

Burke, G. I., \& Jarratt, D. G. (2004). The influence of information and advice on competitive strategy definition in small-and medium-sized enterprises. Qualitative Market Research: An International Journal, 7(2), 126-138.

Carayannis, E. G., Sindakis, S., \& Walter, C. (2015). Business Model Innovation as Lever of Organizational Sustainability. The Journal of Technology Transfer, 40(1), 85-104.

Casadesus-Masanell, R., \& Almirall, E. (2010). Open Versus Closed Innovation. Academy of Management Review, 35(1), 27-47.

Chesbrough, H. W., \& Appleyard, M. M. (2007). Open Innovation and Strategy. California Management Review, 50(1), 57-76. 
Chesbrough, H. (2003). Open Innovation: The New Imperative for Creating and Profiting from Technology. Harvard Business School Press, Boston, MA.

Chiaroni, D., Chiesa, V., \& Frattini, F. (2011). The Open Innovation Journey: How firms dynamically implement the emerging innovation management paradigm. Technovation, 31(1), 34-43.

Comi, A., \& Eppler, M. J. (2009). Building and Managing Strategic Alliances in Technology-Driven Start-Ups: A Critical Review of Literature. IMCA Working Paper.

Conte, A., \& Vivarelli, M. (2014). Succeeding in innovation: key insights on the role of R\&D and technological acquisition drawn from company data. Empirical Economics, 47(4), 1317- 1340.

Coombes, P. H., \& Nicholson, J. D. (2013). Business models and their relationship with marketing: A systematic literature review. Industrial Marketing Management, 42(5), 656-664.

Crick, D., \& Spence, M. (2005). The internationalisation of "high performing" UK high-tech SMEs: A study of planned and unplanned strategies. International Business Review, 14(2), 167-185.

Cummings, J. L., \& Holmberg, S. R. (2012). Best-fit Alliance Partners: The Use of Critical Success Factors in a Comprehensive Partner Selection Process. Long Range Planning, 45(2-3), 136-159.

Dahlander, L., \& Gann, D. M. (2010). How open is innovation? Research Policy, 39(6), 699-709. Daly, H. E. (1999). Globalization vs. Internationalization. Ecological, 31, 31-37.

Damanpour, F., \& Aravind, D. (2012). Managerial Innovation: Conceptions, Processes, and Antecedents. Management and Organization Review, 8(2), 423-454.

Davis, G. F., \& Marquis, C. (2005). Prospects for Organization Theory in the Early Twenty-First Century: Institutional Fields and Mechanisms. Organization Science, 16(4), 332-343.

Da Silva, M., Howells, J. \& Meyer, M. (2018). Innovation intermediaries and collaboration: knowledgebased practices and internal value creation. Research Policy, 47(3), 70-87.

De Marchi, V. (2012). Environmental innovation and R\&D cooperation: Empirical evidence from Spanish manufacturing firms. Research Policy, 41(3), 614-623.

Desouza, K. C., Dombrowski, C., Awazu, Y., Baloh, P., Papagari, S., Jha, K., \& Jha, S. (2007). The Five Stages of Successful Innovation. MIT Sloan Management Review, 48(3), 7-10.

Dierckx, M. A., \& Stroeken, J. H. (1999). Information Technology and Innovation in Small and MediumSized Enterprises. Technological Forecasting and Social Change, 60(2), 149-166.

Doherty, A. M. (2009). Market and partner selection processes in international retail franchising. Journal of Business Research, 62(5), 528-534.

Ebersberger, B., \& Herstad, S. J. (2013). The relationship between international innovation collaboration, intramural R\&D and SMEs' innovation performance: a quantile regression approach. Applied Economics Letters, 20(7), 626-630.

Ebrahim, A., Ahmed, S., \& Taha, Z. (2010). Virtual research and development (R\&D) teams and new product development: A literature review. International Journal of the Physical Sciences, 5(7), 916-930.

Edwards, T., Delbridge, R., \& Munday, M. (2005). Understanding innovation in small and medium-sized enterprises: a process manifest. Technovation, 25(10), 1119-1127.

Eisenhardt, K. M. (1989). Building theories from case study research. Academy of Management Review, 14(4), 532-550.

Eisingerich, A. B., Rubera, G., \& Seifert, M. (2009). Managing Service Innovation and Interorganizational Relationships for Firm Performance: To Commit or Diversify? Journal of Service Research, 11(4), 344-356.

Enkel, E., Gassmann, O., \& Chesbrough, H. (2009). Open R\&D and open innovation: exploring the phenomenon. R\&D Management, 39(4), 311-316.

Ensari, M. Ş., \& Karabay, M. E. (2014). What Helps to Make SMEs Successful in Global Markets? Procedia - Social and Behavioral Sciences, 150, 192-201.

Evanschitzky, H., Eisend, M., Calantone, R. J., \& Jiang, Y. (2012). Success factors of product innovation: An updated meta-analysis. Journal of Product Innovation Management, 26(1994), 21-37. 
Faems, D., Janssens, M., \& Neyens, I. (2012). Alliance Portfolios and Innovation Performance: Connecting Structural and Managerial Perspectives. Group \& Organization Management, 37(2), 241-268.

Felin, T. \& Zenger, T. A. (2014). Closed or open innovation? Problem solving and the governance choice. Research Policy, 43(3), 914-925.

Fitjar, R. D., \& Rodríguez-Pose, A. (2013). Firm collaboration and modes of innovation in Norway. Research Policy, 42(1), 128-138.

Freel, M., \& Robson, P. J. (2017). Appropriation strategies and open innovation in SMEs. International Small Business Journal, 35(5), 578-596.

Francioni, B., Musso, F., \& Cioppi, M. (2015). Decision-maker Characteristics and International Decisions for SMEs. Management Decision, 53(10), 2226-2249.

Galavotti, C., Kuhlmann, A. K. S., Kraft, J. M., Harford, N., \& Petraglia, J. (2008). From innovation to implementation: The long and winding road. American Journal of Community Psychology, 41(34), 314-326.

Gassmann, O., Enkel, E., \& Chesbrough, H. (2010). The future of open innovation as a researchable theory. $R \& D$ Management, 40(3), 213-221.

Ghosh, B. C., Liang, T. W., Meng, T. T., \& Chan, B. (2001). The key success factors, distinctive capabilities, and strategic thrusts of top SMEs in Singapore. Journal of Business Research, 51(3), 209-221.

Heene, A. (1997). The nature of strategic management. Long Range Planning, 30(6), 933-938).

Henttonen, K. (2013, June). Open innovation in SMEs - collaboration modes and strategies in commercialisation phase. Paper presented at the XXIV ISPIM Conference, Innovating in Global Markets, Helsinki, Finland. www.ispim.org: ISPIM.

Hessels, J., \& Parker, S. C. (2013). Constraints, internationalization and growth: A cross-country analysis of European SMEs. Journal of World Business, 48(1), 137-148.

Hill, C.W.L. \& Jones, G.R. (2012). Essentials of strategic management. South Western, Mason, OH.

Hoffman, K., Parejo, M., Bessant, J., \& Perren, L. (1998). Small firms, R\&D, technology and innovation in the UK: a literature review. Technovation, 18(1), 39-55.

Horibe, F. (2003). Innovation, Creativity, and Improvement: Working the right lever to prosperity. The Canadian Manager, 28(2), 20-21, 30.

Hossain, M. (2015). A review of literature on open innovation in small and medium-sized enterprises. Journal of Global Entrepreneurship Research, 5(6), 1-13.

Howard, W. G. (1993). Innovation and intelligence: Matching commercialization needs and information tasks. Competitive Intelligence Review, 4(1), 4-12.

Huang, K. F., \& Yu, C. M. J. (2011). The effect of competitive and non-competitive R\&D collaboration on firm innovation. Journal of Technology Transfer, 36(4), 383-403.

Huang, Y., \& Wilkinson, I. F. (2013). The dynamics and evolution of trust in business relationships. Industrial Marketing Management, 42(3), 455-465.

Hudson, M. \& Smart, M. B. (2001). Theory and practice in SME performance measurement systems. International Journal of Operations \& Production Management, 21(8), 1096.

Huizingh, E. K. R. E. (2011). Open innovation: State of the art and future perspectives. Technovation, $31(1), 2-9$.

Huysmans, J. (2009). Introduction to the Forum on Global Society 'Globalization Theory'. Forum American Bar Association, 3(1), 2009-2009.

Ivanov, F. (2014). Globalization: a road to innovation. Review of International Comparative Management, 15(5), 626- 634.

Johnson, J. H., Arya, B., \& Mirchandani, D. A. (2013). Global integration strategies of small and medium multinationals: Evidence from Taiwan. Journal of World Business, 48(1), 47-57.

Kamalian, A. R., Rashki, M., Hemmat, Z., \& Jolfaie, S. A. D. (2015). Cooperation Networks and Innovation Performance of Small and Medium-Sized Enterprises (SMEs). International Journal of Management, Accounting and Economics, 2(3), 233-242.

70 Journal of Management Policy and Practice Vol. 20(2) 2019 
Kang, S.-W. (2012). An Identification of Unsuccessful, Failure Factors of Technology Innovation and Development in SMEs: A Case Study of Components and Material Industry. International Journal of Business and Management, 7(19), 16-30.

Kaufmann, A., \& Tödtling, F. (2002). How effective is innovation support for SMEs? An analysis of the region of Upper Austria. Technovation, 22(3), 147-159.

Keizer, J. A., Dijkstra, L., \& Halman, J. I. M. (2001). Explaining innovative efforts of SMEs. An exploratory survey among SMEs in the mechanical and electrical engineering sector in The Netherlands. Technovation, 22(1), 1- 13.

Kennedy, A., \& Keeney, K. (2009). Strategic partnerships and the internationalisation process of software SMEs. Service Business, 3(3), 259-273.

Khalifa, A. S. (2008). The "strategy frame" and the four Es of strategy drivers. Management Decision, 46(6), 894- 917.

Kim, W.-Y., \& Kim, E.-K. (2009). Does Firm Size Matter in Explaining Firm Performance? The Case of Korean SMEs in an Open Economy. Paper presented at the ICSB Conference, Washington, DC.

Kluyver, C. A. de. (2010). Fundamentals of global strategy. A business model approach. Business Expert Press. New York, NY.

Kotlica, S. (2002). Globalization and international trade. Zbornik Matice Srpske Za Drustvene Nauke, (112-113), 245-276.

Laanti, R., Gabrielsson, M., \& Gabrielsson, P. (2007). The globalization strategies of business-to-business born global firms in the wireless technology industry. Industrial Marketing Management, 36(8), $1104-1117$.

Laursen, K., \& Salter, A. (2006). Open for innovation: The role of openness in explaining innovation performance among U.K. manufacturing firms. Strategic Management Journal, 27(2), 131-150.

Lawson, B. \& Samson, D. (2001). Developing Innovation Capability in Organisations: a Dynamic Capabilities Approach. International Journal of Innovation Management, 5(3), 377-400.

Lazzarotti, V., \& Manzini, R. (2009). Different Modes of Open Innovation: A Theoretical Framework And An Empirical Study. International Journal of Innovation Management, 13(4), 615-636.

Lee, S., Park, G., Yoon, B., \& Park, J. (2010). Open innovation in SMEs - An intermediated network model. Research Policy, 39(2), 290-300.

Lichtenthaler, U. (2011). Open Innovation: Past Research, Current Debates, and Future Directions.Academy of Management Perspectives, 25(1), 75-93.

Lin, C., Wu, Y.-J., Chang, C., Wang, W., \& Lee, C.-Y. (2012). The alliance innovation performance of R\&D alliances -the absorptive capacity perspective. Technovation, 32(5), 282-292.

Lin, F. J., \& Lin, Y. H. (2016). The effect of network relationship on the performance of SMEs. Journal of Business Research, 69(5), 1780-1784.

Little, A. W., \& Green, A. (2009). Successful globalisation, education and sustainable development. International Journal of Educational Development Successful Globalisation, Education and Sustainable Development, 29(2), 166-174.

Lounsbury, M., \& Beckman, C. M. (2015). Celebrating organization theory. Journal of Management Studies, 52(2), 288-308.

Lawson, B., \& Samson, D. (2001). Developing Innovation Capability in Organisations: a Dynamic Capabilities Approach. International Journal of Innovation Management, 5(3), 377-400.

Mangematin, V., Sapsed, J., \& Schüßler, E. (2014). Disassembly and reassembly: An introduction to the Special Issue on digital technology and creative industries. Technological Forecasting and Social Change, 83, 1-9.

Massa, S., \& Testa, S. (2008). Innovation and SMEs: Misaligned perspectives and goals among entrepreneurs, academics and policy makers. Technovation, 28(7), 393-407.

Mcpherson, M. K., \& Vonortas, N. S. (2011). Networks and Strategic Options for Innovative Performance in KBEs. AEGIS, 1.7.3.

Meyer, J. W. (2007). Globalization: Theory and Trends. International Journal of Comparative Sociology, 48(4), 261-273. 
Michelfelder, I., \& Kratzer, J. (2013). Why and how combining strong and weak ties within a single interorganizational R\&D collaboration outperforms other collaboration structures. Journal of Product Innovation Management, 30(6), 1159-1177.

Mina, A., Bascavusoglu-Moreau, E., \& Hugues, A. (2014). Open service innovation and the firm's search for external knowledge. Research policy, 43(5), 853-866.

Narula, R. (2004). R\&D collaboration by SMEs: new opportunities and limitations in the face of globalisation. Technovation, 24(2), 153-161.

Natário, M. M., Almeida, J. P., \& Couto, M. H. (2012). Innovation processes of SMEs in less favored municipalities of Portugal. Investigaciones Regionales, 22, 81-103.

Nik Ab Halim, N. A., \& Zain, M. S. N. (2011). The Internationalization Theory and Malaysian Small Medium Enterprises (SMEs). International Journal of Trade, Economics and Finance, 2(4), 318 322.

Nordman, E. R., \& Tolstoy, D. (2016). The impact of opportunity connectedness on innovation in SMEs' foreign-market relationships. Technovation, 58/59, 1-11.

O’Regan, N., Ghobadian, A. \& Sims, M. (2006). Fast tracking innovation in manufacturing SMEs. Technovation, 26(2), 251-261.

Overby, M. L. (2005). Partner Selection Criteria in Strategic Alliances: When to Ally with Weak Partners. (Working Paper No. 05-07). Danish Research Unit for Industrial Dynamics, www.druid.dk

Owen, S., \& Yawson, A. (2015). R\&D intensity, cross-border strategic alliances, and valuation effects. Journal of International Financial Markets, Institutions and Money, 35, 1-17.

Owolabi, S. W., Owolabi, O. O., Adeleke, Y. S., \& Abubakar, K. (2012). Strategic Approach to R and D Commercialization in Nigeria. International Journal of Innovation, Management and Technology, 3(4), 382-386.

Parisi, M. L., Schiantarelli, F., \& Sembenelli, A. (2006). Productivity, innovation and R\&D: Micro evidence for Italy. European Economic Review, 50(8), 2037-2061.

Parsons, E.J., Goddard, E.P., Seabrooke-Spencer, D.J., \& White, L.A. (2012, 17-20 June). The Case for a Systems Approach to Manage Technological Innovation. Paper presented at the XXIII ISPIM Conference, Barcelona, Spain. www.ispim.org: ISPIM.

Patra, S. K., \& Krishna, V. V. (2015). Globalization of R\&D and open innovation: linkages of foreign R\&D centers in India. Journal of Open Innovation: Technology, Market, and Complexity, 1(1), 124.

Peters, B., \& Schmiele, A. (2010). The influence of international dispersed vs. home-based $R \& D$ on innovation performance. ZEW Working Paper No. 10-102. Centre for European Economic Research, Mannheim, Germany. http://ftp.zew.de/pub/zew-docs/dp/dp10102.

Phillips, J., \& Innovation, O. V. O. (2010). Open Innovation Typology. International Journal of Innovation Science, 2(4).

Raymond, L., \& St-Pierre, J. (2010). R\&D as a determinant of innovation in manufacturing SMEs: An attempt at empirical clarification. Technovation, 30(1), 48-56.

Rhee, J., Park, T., \& Lee, D. H. (2010). Drivers of innovativeness and performance for innovative SMEs in South Korea: Mediation of learning orientation. Technovation, 30(1), 65-75.

Rosenberg, J. (2007). And the Definition of Globalization Is? A Reply to "In at the Death?" by Barrie Axford. Globalizations, 4(3), 417-421.

Rosenbusch, N., Brinckmann, J., \& Bausch, A. (2011). Is innovation always beneficial? A meta-analysis of the relationship between innovation and performance in SMEs. Journal of Business Venturing, 26(4), 441-457.

Saebi, T. \& Foss, N. J. (2015). Business models for open innovation: matching heterogeneous open innovation strategies with business model dimensions. European Management Journal, 33(3), 201-213.

72 Journal of Management Policy and Practice Vol. 20(2) 2019 
Sánchez-Navas, A., \& Ferràs-Hernández, X. (2015). The impact of individual relationships on performance and reformation of R\&D alliances. Journal of Industrial Engineering and Management, 8(4), 1270-1287.

Santamaria, L., \& Surroca, J. (2011). Matching the goals and impacts of R\&D collaboration. European Management Review, 8(2), 95-109.

Scagnelli, S. D., \& Cisi, M. (2014). Approaches to Shared Value Creation: CSR 2.0 or Something More? Insights and Issues about the New Sustainability Perspective, 5(2), 10-13.

Schneckenberg, D., Velamuri, V. K., Comberg, C., \& Spieth, P. (2015). Business model innovation and decision- making: Uncovering mechanisms for coping with uncertainty. $R \& D$ Management, 47(3), 1-35.

Solesvik, M. Z., \& Gulbrandsen, M. (2013). Partner Selection for Open Innovation. Technology Innovation Management Review, 3(4), 6-11.

Su, Y. S., Tsang, E. W. K., \& Peng, M. W. (2009). How do internal capabilities and external partnerships affect innovativeness? Asia Pacific Journal of Management, 26(2), 309-331.

Suh, Y., \& Kim, M.-S. (2012). Effects of SME collaboration on R \& D in the service sector in open innovation. Innovation: Management, Policy \& Practice, 14(3), 349-362.

Sung-Wook, K. (2012). An Identification of Unsuccessful, Failure Factors of Technology Innovation and Development in SMEs: A Case Study of Components and Material Industry. International Journal of Business and Management, 7(19), 16.

Tao, L. (2010). Towards an integrated framework for managing the process of innovation. $R \& D$ Management, 40(1), 19.

Tavassoli, S., \& Karlsson, C. (2015). Persistence of various types of innovation analyzed and explained. Research Policy, 44(10), 1887-1901.

Temel, S., Mention, A. L., \& Torkkeli, M. (2013). The impact of cooperation on firms' innovation propensity in emerging economies. Journal of Technology Management and Innovation, 8(1), 54-64.

Thomas, N. (2014). The Role of SMEs in Employment Creation and Economic Growth in Selected Countries. International Journal of Education and Research, 2(12), 461-472.

Thorgren, S., Wincent, J., \& Örtqvist, D. (2009). Designing interorganizational networks for innovation: An empirical examination of network configuration, formation and governance. Journal of Engineering and Technology Management, 26(3), 148-166.

Thorgren, S., Wincent, J., Örtqvist, D., Thomas, N., Network, R. S., Meissner, D., Daly, H. E. (2012). How to Drive Innovation and Business Growth: Leveraging Emerging Technology for Sustainable Growth. Technovation, 31(1), 1-10.

Todeva, E., \& Knoke, D. (2005). Strategic alliances and models of collaboration. Management Decision, $43(1), 123-148$.

Tohidi, H., \& Jabbari, M. M. (2012). Technological Innovation Process Improvement. Procedia Technology, 1, 517-520.

Tsou, H.-T., Cheng, C. C. J., \& Hsu, H.-Y. (2015). Selecting business partner for service delivery coinnovation and competitive advantage. Management Decision, 53(9), 2107-2134.

Un, C. A., \& Asakawa, K. (2015). Types of R\&D collaborations and process innovation: The benefit of collaborating upstream in the knowledge chain. Journal of Product Innovation Management, $32(1), 138-153$.

Valkokari, K., \& Helander, N. (2007). Knowledge management in different types of strategic SME networks. Management Research News, 30(8), 597-608.

Van de Vrande, V., de Jong, J. P. J., Vanhaverbeke, W., \& de Rochemont, M. (2009). Open innovation in SMEs: Trends, motives and management challenges. Technovation, 29(6-7), 423-437.

Veer, T., Lorenz, A., \& Blind, K. (2016). How open is too open? The mitigating role of appropriation mechanisms in R\&D cooperation settings. $R \&$ D Management, 46(53), 1113-1128. 
Verweij, G., Pearl, M., Shelton, T., Jasmin, Y., \& Eckert, D. (2012). How to Drive Innovation and Business Growth: Leveraging Emerging Technology for Sustainable Growth. PwC Advisory Oracle Practice. Retrieved from www.pwc.com.

Walsh, J. P., Meyer, A. D., \& Schoonhoven, C. B. (2006). A Future for Organization Theory: Living in and Living with Changing Organizations. Organization Science, 17(5), 657-671.

Wasniewski, K. (2010). Corporate strategies - the institutional approach. Journal of Advanced Research in Management, 2(1), 46-65.

Wikhamn, W., \& Styhre, A. (2016). Open innovation in SMEs: a study of the Swedish biopharmaceutical industry. Journal of Small Business and Enterpreneurship, 28(2), 169-185.

Wincent, J., Anokhin, S., \& Örtqvist, D. (2010). Does network board capital matter? A study of innovative performance in strategic SME networks. Journal of Business Research, 63(3), 265275.

Wu, W. Y., Shih, H. A., \& Chan, H. C. (2009). The analytic network process for partner selection criteria in strategic alliances. Expert Systems with Applications, 36(3 Part 1), 4646-4653.

Wynarczyk, P., Piperopoulos, P., \& McAdam, M. (2013). Open innovation in small and medium-sized enterprises: An overview. International Small Business Journal, 31(3), 240-255.

Zain, M., \& Ng, S. I. (2006). The impacts of network relationships on SMEs' internationalization process. Thunderbird International Business Review, 48(2), 183-205.

Zeng, S. X., Xie, X. M., \& Tam, C. M. (2010). Relationship between cooperation networks and innovation performance of SMEs. Technovation, 30(3), 181-194.

Zhao, S., Sun, Y. \& Xu, X. (2016). Research in open innovation performance: a review. Information technology Management, 17(3), 279-287.

Zhu, Z., \& Huang, F. (2012). The Effect of R \& D Investment on Firms' Financial Performance: Evidence from the Chinese Listed IT Firms. Modern Economy, 3, 915-919.

Zobel, A.-K. \& Hagedoorn, J. (2018). Implications of open innovation for organizational boundaries and the governance of contractual relations. Academy of Management Perspectives, In press.

Zou, S., \& Cavusgil, S. T. (1996). Global strategy: a review and an integrated conceptual framework. European Journal of Marketing, 30(1), 52-69.

Zynga, A., Diener, K., Ihl, C., Luttgens, D., Piller, F. \& Scherb, B. (2018). Making open innovation stick. A study of open innovation implementation in 756 global organizations. Research Technology Management, 61(4), 16-25.

74 Journal of Management Policy and Practice Vol. 20(2) 2019 